\title{
Peningkatan Kualitas Hidup Lansia dalam Penanganan Stroke bagi Kader PKK dan Kesehatan di Gilingan, Banjarsari, Surakarta
}

\author{
Stroke Management of Family Empowerment and Welfare (PKK) and Community \\ Health Workers (Kader) to Improve the Quality of Life of Elderly in Gilingan, \\ Banjarsari, Surakarta
}

\author{
Novena Yety Lindawati*, Endah Kurniawati, Dian Puspitasari, Diah Pratimasari \\ Program Studi S1 Farmasi, Sekolah Tinggi Ilmu Kesehatan Nasional, Surakarta \\ *novena yl@yahoo.com
}

Riwayat Artikel: Dikirim 4 Oktober 2018; Diterima 28 Mei 2019; Diterbitkan 31 Mei 2019

\begin{abstract}
Abstrak
Stroke merupakan penyebab kecacatan nomor satu dan penyebab kematian nomor tiga setelah penyakit jantung dan kanker baik dinegara maju maupun berkembang. Di Indonesia, stroke merupakan penyebab kematian pada semua kelompok umur, dengan proporsi tertinggi pada usia 55-64 tahun mencapai, 26,8\% baik diperkotaan maupun dipedesaan. Kegiatan pengabdian masyarakat dalam bentuk promotif, preventif, kuratif, dan rehabilitatif dengan memberikan penyuluhan tentang penyakit stroke dan penanganannya secara alami, workshop pembuatan minuman pencegah stroke, serta pelatihan senam pencegah stroke. Evaluasi kegiatan dilakukan dengan metode pretest dan postest terhadap materi penyuluhan yang diberikan serta kuisioner tentang pelaksanaan kegiatan yang telah dilakukan. Kegiatan pengabdian masyarakat diikuti oleh 43 peserta yang terdiri dari kader PKK dan kesehatan serta perwakilan lansia dari tiap RW di Gilingan, Banjarsari, Surakarta. Hasil kegiatan ini menunjukkan adanya peningkatan persentase tingkat pengetahuan dan pemahaman peserta mengenai penyakit stroke setelah pemberian penyuluhan "Mengenal Penyakit Stroke" dari 35\% menjadi 95\%. Peningkatan jumlah peserta yang memahami cara penanganan penyakit stroke secara alami juga terlihat setelah pemberian penyuluhan "Pemanfaatan Obat Alam Indonesia untuk Terapi Penyakit Stroke" dari 42\% menjadi 93\%. Evaluasi terhadap pelaksanaan kegiatan pengabdian ini juga menunjukkan hasil yang sangat baik terhadap tema yang diambil sebanyak 86,05\% peserta memilih sangat menarik dan 13,95\% memilih menarik. Kegiatan pengabdian ini meningkatkan pengetahuan, pemahaman, dan wawasan mengenai penyakit stroke dan penanganannya secara alami bagi Kader PKK dan Kesehatan serta perwakilan para lansia di Gilingan, Banjarsari, Surakarta sehingga dapat mensosialisasikan ke seluruh masyarakat serta mengurangi angka kejadian stroke di daerah tersebut.
\end{abstract}

Kata Kunci : stroke, pencegahan dan penanganan alami stroke, kader PKK dan kesehatan

\begin{abstract}
Stroke is one of the cause of disability and death (its rank is after heart disease and cancer) worldwide. In Indonesia, stroke is the cause of death in all age groups, with the highest proportion is at the age of 55-64 years reaching 26.8\% both in urban and rural areas. Community service activities in stroke promotive, preventive, curative, and rehabilitative forms was held by providing counseling about stroke and how to handle it naturally, workshops on making health drinks to prevent strokes, as well as stroke prevention exercises. Evaluation of activities was carried out with the pretest and posttest method of counseling material provided as well as questionnaires about the implementation of activities that had been carried out. Community service activities were attended by 43 participants consisting of PKK workers (kader), community health workers (kader), and elderly representatives from each $\mathrm{RW}$ in Gilingan, Banjarsari, Surakarta. The results of this activity indicate an increase in the percentage of the level of knowledge and understanding of participants regarding stroke after giving counseling "Recognizing Stroke" from 35\% to 95\%. An increase in the number of participants who understand how to deal with stroke naturally is also seen after giving counseling "Utilization of Indonesian Natural Herbs for Stroke Therapy" from 42\% to 93\%. The evaluation of the implementation of this service activity also showed very good results on the theme taken as many as $86.05 \%$ of the participants chose very interesting and $13.95 \%$ chose interesting. This service activity increases knowledge, understanding, and insight into stroke and its handling naturally for PKK kader, community health kader and representatives of the elderly in Gilingan, Banjarsari, Surakarta so that they can socialize to the whole community and reduce the incidence of stroke in the area.
\end{abstract}

Keywords: stroke, prevention and handling natural stroke, PKK and health workers 


\section{PENDAHULUAN}

Stroke merupakan penyebab kecacatan nomor satu dan penyebab kematian nomor tiga setelah penyakit jantung dan kanker baik dinegara maju maupun berkembang. Beban akibat stroke terutama kecacatan dapat menimbulkan beban biaya yang tinggi baik oleh penderita, keluarga, masyarakat dan negara. Di Indonesia, stroke merupakan penyebab kematian pada semua kelompok umur, dengan proporsi tertinggi pada usia 55-64 tahun mencapai, 26,8\% baik diperkotaan maupun dipedesaan. Stroke disebabkan oleh banyak faktor, yang sebagian besar bisa dikendalikan. Stroke merupakan akibat dari life style (gaya hidup) manusia modern yang tidak sehat seperti konsumsi makanan yang tinggi kolesterol dan rendah serat, kurang aktivitas fisik (berolahraga), akibat stres/ kelelahan, konsumsi alkohol berlebihan, kebiasaan merokok. Berbagai faktor risiko ini selanjutnya akan mengakibatkan pengerasan pembuluh arteri (arteriosklerosis), sebagai pemicu stroke (Diwanto, 2009).

Kelurahan Gilingan adalah kelurahan yang berada di utara kota Surakarta dan termasuk dalam daerah pinggiran, dan di Kelurahan Gilingan sebagian penduduknya adalah pendatang. Pada kelurahan Gilingan, perkembangan penduduk kian pesat menjadikan kelurahan ini memiliki pemukiman yang sangat padat dan memiliki kompleksitas masalah pemukiman. Laporan Monografi Dinamis Kelurahan Gilingan tahun 2014 menyebutkan wilayah ini dihuni oleh 21.979 jiwa yang terdiri dari 10.804 jiwa merupakan penduduk laki-laki dan dan 11.115 jiwa penduduk perempuan dengan jumlah kepala keluarga sebesar 4.515. Pada data tersebut jumlah lansia dengan usia 5760 tahun cukup banyak mencapai 3.041 jiwa.

Pengabdian kepada masyarakat adalah bentuk tanggung jawab sosial atas pengembangan dan penguasaan ilmu pengetahuan, teknologi, dan seni suatu institusi, langsung kepada masyarakat secara melembaga melalui metode ilmiah yang berorientasi pada pemecahan masalah.
Tujuan kegiatan ini adalah mempercepat proses peningkatan kemampuan sumber daya manusia sesuai tuntutan dinamika pembangunan yang berpedoman pada pengertian konsep pendidikan seumur hidup. Kegiatan pengabdian masyarakat ini kami tujukan masyarakat kelurahan Gilingan, Banjarsari, Surakarta khususnya para lansia dan kader kesehatan dengan tema "Peningkatan Kualitas Hidup Lansia dalam Penanganan Stroke" bagi Kader PKK dan Kesehatan di Kelurahan Gilingan, Kecamatan Banjarsari, Surakarta. Kegiatan pengabdian masyarakat dalam bentuk promotif, preventif, kuratif, dan rehabilitatif dengan memberikan penyuluhan tentang penyakit stroke dan penanganannya secara alami serta workshop pembuatan minuman pencegah stroke dan senam ringan untuk pencegahan stroke dan perbaikan life style sehingga dapat meningkatkan kualitas hidup atau kesehatan masyarakat kelurahan Gilingan serta dapat menurunkan angka kesakitan, kecacatan, dan kematian akibat stroke.

\section{METODOLOGI PENGABDIAN}

\section{Sasaran}

Sasaran yang dianggap strategis adalah Kader PKK dan Kesehatan serta perwakilan Lansia dari tiap RW di kelurahan Gilingan, Banjarsari, Surakarta. Pemilihan sasaran ini diharapkan dapat mensosialisasikan hasil dari kegiatan ini kepada seluruh warga yang berkaitan dengan deteksi dini penyakit stroke dan penanganan stroke tersebut menggunakan bahan alami serta melalui perubahan gaya hidup.

\section{Metode Pelaksanaan}

Dalam rangka peningkatan pemahaman, pengetahuan bagi kader PKK dan Kesehatan serta perwakilan lansia mengenai Stroke dan penatalaksanaannya maka dilakukan dalam bentuk 4 segmen kegiatan; tahap pertama penyuluhan tentang "Deteksi Dini Penyakit Stroke dan Pencegahan Pertama" dan penyuluhan tentang "Pemanfaatan Obat Bahan Alam 
untuk Terapi Stroke", tahap kedua diberikan workshop pembuatan minuman pencegah Stroke, tahap ketiga dilakukan diskusi bersama-sama, dan tahap keempat sebagai penutup dilakukan senam kesegaran untuk pencegahan Stroke. Peserta diberikan pretest dan postest untuk evaluasi terhadap pemahaman materi penyuluhan serta kuisioner tentang pelaksanaan kegiatan pengabdian masyarakat ini.

\section{HASIL DAN PEMBAHASAN}

Kegiatan program pengabdian masyarakat yang dilakukan bertema "Peningkatan Kualitas Hidup Lansia dalam Penanganan Stroke" bagi Kader PKK dan Kesehatan di Kelurahan Gilingan, Banjarsari, Surakarta. Stroke merupakan suatu gangguan fungsional otak yang terjadi secara mendadak dengan tanda dan gejala klinik baik fokal maupun global yang berlangsung lebih dari 24 jam, atau dapat menimbulkan kematian, disebabkan oleh gangguan peredaran darah otak. Faktor-faktor risiko stroke meliputi: faktor-faktor yang dapat dimodifikasi seperti hipertensi, diabetes melitus, penyakit jantung, dislipidemia, serangan iskemik sepintas (TIA), obesitas, konsumsi alkohol, merokok, peningkatan kadar hematokrit, peningkatan kadar fibrinogen, dan migren dan faktor-faktor yang tidak dapat dimodifikasi seperti usia, jenis kelamin, dan hereditas (Gofir, 2009). Bahaya stroke ini menjadi perhatian tersendiri bagi pelaksana pengabdian serta melihat banyaknya warga lansia di kelurahan Gilingan, Banjarsari, Surakarta yang membutuhkan informasi terkait stroke dan penatalaksanaannya berdasarkan hasil survey secara lisan melalui kelurahan maupun ketua RW setempat. Program pengabdian masyarakat juga menjadi sarana dalam menyampaikan dan menerapkan ilmu serta bentuk pelaksanaan Tri Dharma Perguruan Tinggi.

Kegiatan pengabdian masyarakat yang dilakukan mendapat dukungan penuh dari kelurahan Gilingan, Banjarsari, Surakarta. Peserta yang mengikuti pengabdian masyarakat sesuai dengan target dan sasaran bahkan lebih yang awal mula direncanakan untuk 30 peserta menjadi 43 peserta pada pelaksanaanya yaitu kader PKK, kader kesehatan, dan perwakilan lansia dari masing-masing rukun warga. Dalam kegiatan ini juga dihadiri oleh Kepala Kelurahan Gilingan, Banjarsari, Surakarta berserta jajarannya termasuk bapak ketua RW dari kelurahan tersebut.

\section{Pelaksanaan Kegiatan}

Kegiatan Pengabdian Masyarakat diawali penyuluhan dengan tema pertama "Mengenal Penyakit Stroke" yang dibawakan oleh Endah Kurniawati, S. Farm., M.Sc., Apt (gambar 1), setelah pretest dan sambutan dari Kepala Kelurahan Gilingan, Banjarsari, Surakarta. Pada penyuluhan ini disampaikan tentang pengertian stroke, tipe stroke dimana ada stoke iskemik dan hemoragik, penyebab dari stroke, bagaimana tanda dan gejala stroke (wajah, lengan, suara) bagaimana cara melakukan deteksi dini dari serangan stroke, faktor resiko yang dapat meningkatkan terjadinya stroke, siapa saja yang berisiko terkena stroke, pengaruh stroke ke organ tubuh. Penatalaksanaan penyakit stroke pada stadium Hiperakut dengan penanganan di Instalasi Rawat Darurat, pada stadium akut dengan penanganan faktor etiologik, terapi fisik, okupasi, wicara, psikologis, serta telaah sosial, dan pada stadium subakut dilakukan terapi kognitif, tingkah laku, menelan, dan lain-lain (Setyopranoto, 2011: 247). Pada penyuluhan ini juga dijelaskan terapi stroke meliputi terapi non farmakologi seperti perubahan gaya hidup serta diet tinggi buahan citrus dan sayuran hijau (Goldszmidt \& Caplan, 2011), melakukan aktivitas fisik (Sweetman, 2009). Pada terapi farmakologi seperti pemberian antithrombotik dan neuroproteksi (Fagan \& Hess, 2008). Pada rehabilitasi pasca stroke disampaikan meliputi terapi wicara, terapi fisik, dan terapi occupasional (Aminoff, Greenberg, \& Simon, 2009). 
Gambar 1.

Pemberian penyuluhan dengan tema

"Mengenal Penyakit Stroke" oleh Endah

Kurniawati, S. Farm., M.Sc., Apt.

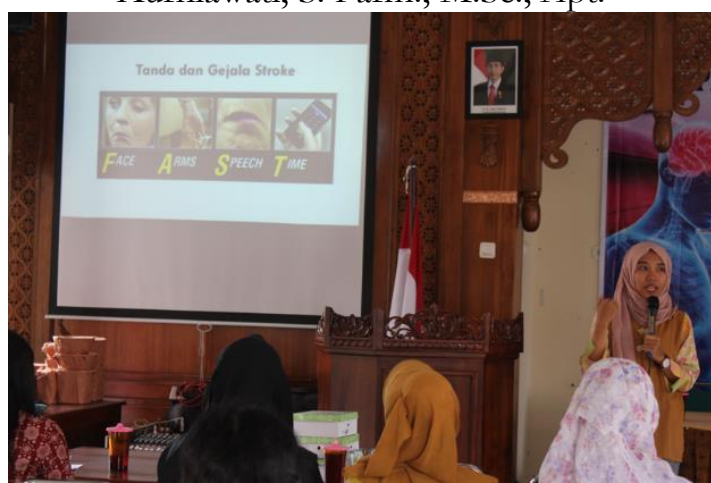

Acara dilanjutkan dengan penyuluhan kedua dengan Tema "Pemanfaatan Obat Alam Indonesia untuk Terapi Stroke". Dalam materi yang disampaikan oleh Novena Yety Lindawati, S. Farm., M.Sc., Apt. dijelaskan mengenai tanaman obat, sayuran, dan buah yang dapat digunakan untuk terapi stroke serta mekanisme aksinya. Tanaman yang sering digunakan untuk terapi tersebut antara lain Bawang Putih, Jahe, Mengkudu, Daun Dewa, formula ramuan yang terdiri dari beberapa simplisia yaitu jahe, mengkudu, daun dewa, dan daun cermai serta madu yang diolah bersama-sama. Tanaman yang digunakan lainnya seperti Sambiloto, Pegagan, Jinten, Kunir, Formula ramuan lainnya campuran temulawak, asam jawa, bawang putih dan Sambiloto. Buah dan sayur yang sering digunakan dalam terapi alternatif penyakit stroke antara lain wortel, bayam, nanas, apokat, pepaya, jeruk nipis, tomat, dan seledri. Bahan yang sering kita jumpai dan bersifat alami yang juga dapat diguanakan untuk terapi stroke seperti madu, minyak zaitun, dan teh (gambar 2).
Gambar 2.

Pemberian penyuluhan dengan tema

"Pemanfaatan Obat Alam Indonesia untuk Terapi Stroke" oleh Novena Yety Lindawati, S.Farm., M.Sc., Apt.

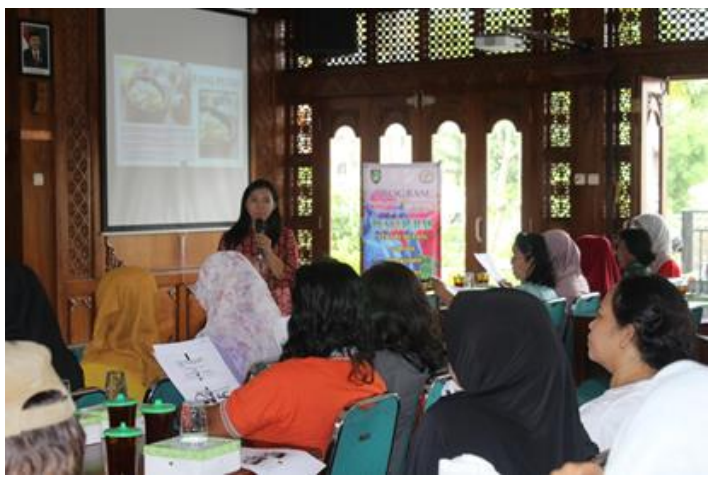

Kegiatan pengabdian dilanjutkan dengan acara workshop "Pemanfaatan Buah dan Sayur untuk Terapi Stroke yang diibawakan oleh Dian Puspitasari, S. Farm., M.Sc., Apt (Gambar 3). Pada workshop ini disajikan pembuatan Jus Timun Seledri, Jus Labu kuning Tomat, dan Jus Nanas. Acara selanjutnya adalah sesi diskusi, antusiasme dari peserta pada sesi tanya jawab dapat dilihat dengan banyaknya pertanyaan yang diberikan peserta. Beberapa pertanyaan yang diajukan peserta tipe stroke, terapi kombinasi antara obat kimia dengan obat dari bahan alam, dan efek dari penggunaan obat yang berasal dari bahan alam.

Gambar 3.

Workshop "Pemanfaatan Buah dan Sayur untuk Terapi Stroke yang diibawakan oleh

Dian Puspitasari, S. Farm., M.Sc., Apt.

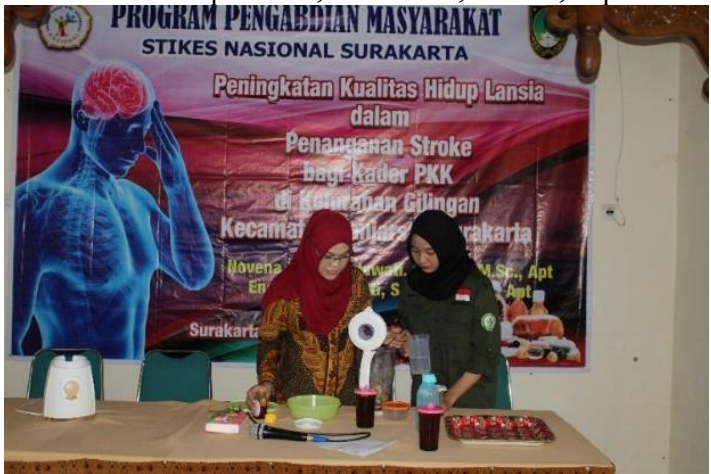


Kegiatan keempat dilakukan dilakukan senam kesegaran untuk pencegahan stroke. Senam dipandu oleh Diah Pratimasari, M.Farm., Apt bersama dengan mahasiswa dengan sarana pemutaran video untuk menambah semarak kegiatan (gambar 4). Setelah kegiatan tersebut dilakukan postest dan penutupan (gambar 5).

Gambar 4.

Senam untuk pencegahan stroke oleh Diah Pratimasari, M.Farm., Apt dan mahasiswa

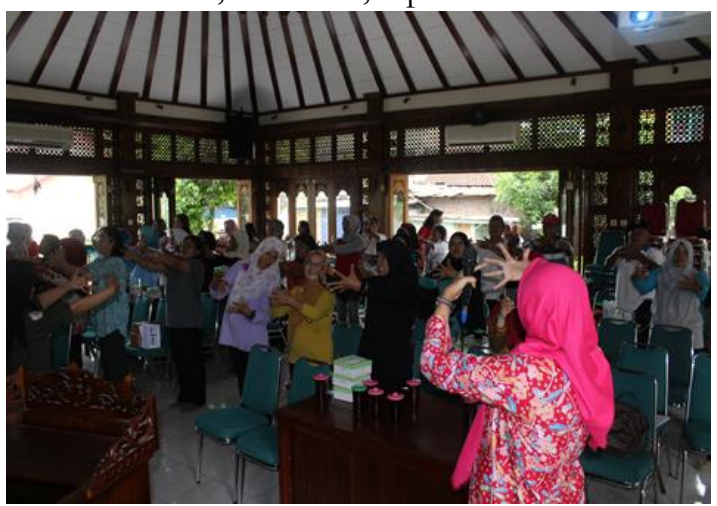

Gambar 5.

Foto Bersama setelah kegiatan penutupan

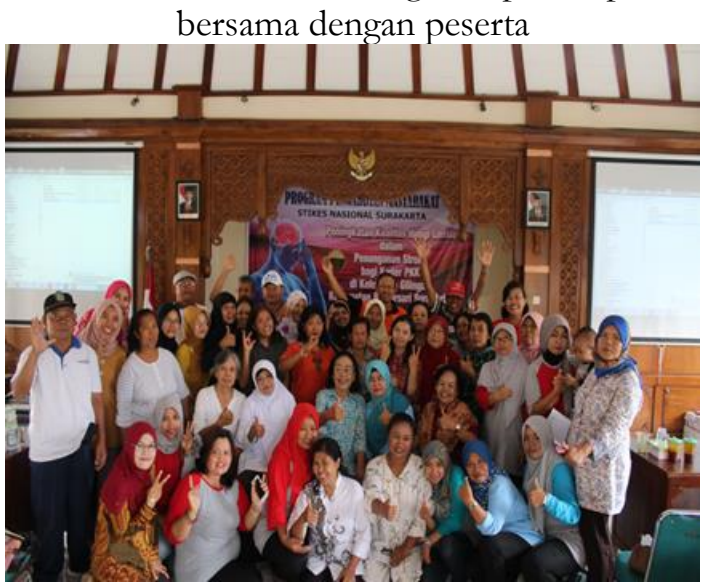

\section{Evaluasi Kegiatan}

Hasil pretest dari peserta terkait dengan materi "Mengenal Penyakit Stroke" menunjukkan terdapat $35 \%$ peserta yang sudah mengerti terhadap materi yang akan diberikan dan $65 \%$ peserta masih belum mengerti materi yang akan diberikan dari total 43 peserta (gambar 6). Hal ini menunjukkan ada lebih dari setengah jumlah peserta belum memahami tentang penyakit stroke, gejala, dan penatalaksanaannya.

Gambar 6.

Persentase hasil pretest dan postest pada evaluasi kegiatan penyuluhan dengan materi "Mengenal Penyakit Stroke"

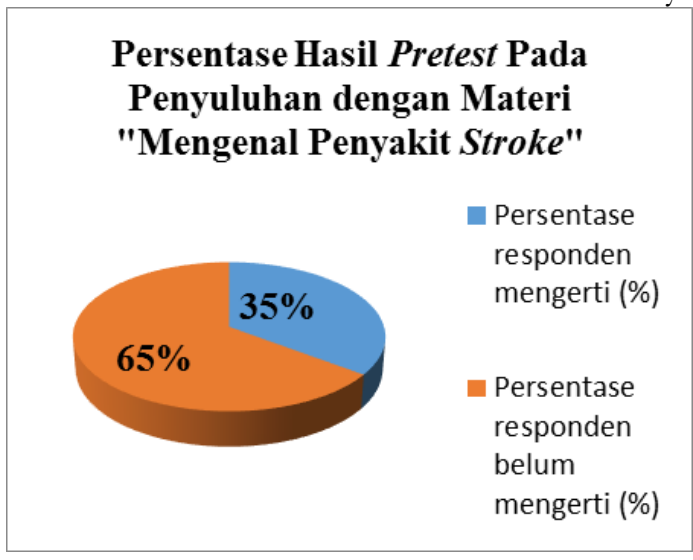

Terdapat peningkatan persentase tingkat pengetahuan peserta mengenai penyakit stroke setelah pemberian materi "Mengenal Penyakit Stroke" Ada 95\% responden atau peserta telah mengerti materi dan hanya $5 \%$ peserta yang masih belum mengerti (gambar 6).

\section{Persentase Hasil Postest Pada Penyuluhan dengan Materi " Mengenal Penyakit Stroke"}

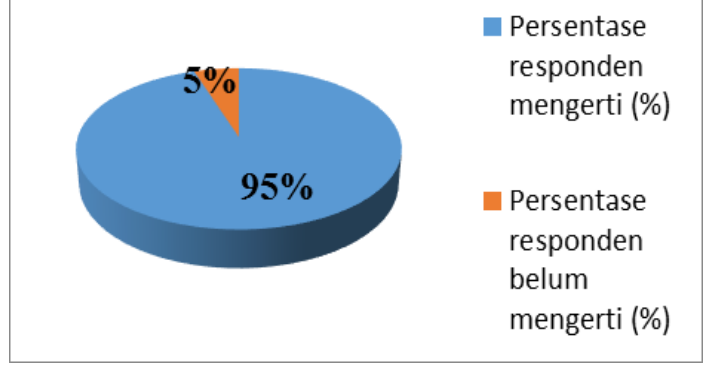

Pada evaluasi pretest materi "Pemanfaatan Obat Alam Indonesia untuk Terapi Stroke" dapat dilihat peserta belum memahami manfaat dari penggunaan obat alam sekitar untuk terapi alternatif stroke dengan persentase mencapai 59\% sedangkan yang sudah memahami mencapai 
$41 \%$ (gambar 7). Hal ini juga menunjukkan materi yang diberikan sangat dibutuhkan peserta terutama pemanfaatan bahan alam yang mudah didapat dan memiliki efek samping yang relatif lebih ringan. Beberapa bahan alam sekitar yang digunakan untuk mengevaluasi tingkat pemahaman peserta antara lain terkait dengan Pemanfaatan minyak zaitun, pemilihan minuman yang tepat untuk terapi stroke, pemilihan sayuran dan buah yang dapat digunakan untuk terapi alternatif penyakit stroke, serta pemahaman tentang mekanisme aksi secara umum dari pemanfaatan bahan alam dalam mengurangi gejala penyakit stroke. Hasil postest menunjukkan adanya kenaikan persentase pemahaman peserta menjadi $93 \%$ sedangkan yang masih belum memahami berkurang menjadi 7\% (gambar 7). Adanya peningkatan jumlah peserta yang mengerti terhadap materi yang diberikan menunjukkan kegiatan yang dilakukan berhasil.

\section{Gambar 7.}

Persentase hasil pretest dan postest pada evaluasi kegiatan penyuluhan dengan materi "Pemanfaatan Obat Alam Indonesia untuk Terapi Stroke"

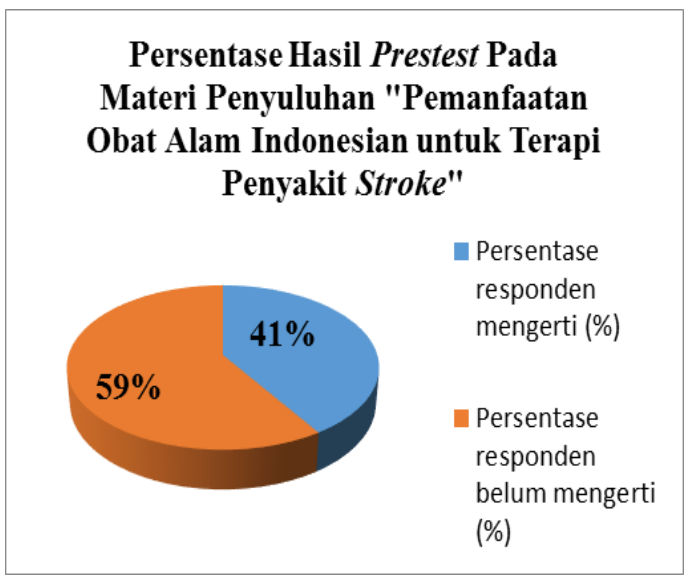

Evaluasi juga dilakukan terhadap tingkat kepuasan peserta kegiatan pengabdian yang dilaksanakan mulai dari kepuasan peserta terhadap tema yang diambil (kuisioner terlampir). Hasil
Persentase Hasil Postest Pada Materi Penyuluhan"Pemanfaatan Obat Alam Indonesia untuk Terapi Penyakit Stroke"

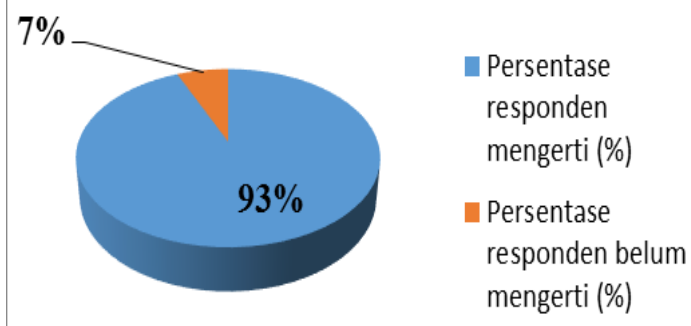

Gambar 8 .

Persentase hasil kuesioner kepuasan peserta terhadap tema kegiatan pengabdian yang dilaksanakan

\begin{tabular}{|ccccc|}
\hline \multicolumn{5}{c|}{ Persentase Hasil Kuesioner } \\
\\
86.05 & & & & \\
& & & & \\
\hline $\begin{array}{c}\text { Sangat } \\
\text { menarik }\end{array}$ & Menarik & $\begin{array}{c}\text { Cukup } \\
\text { menarik }\end{array}$ & $\begin{array}{c}\text { Kurang } \\
\text { menarik }\end{array}$ & $\begin{array}{c}\text { Tidak } \\
\text { menarik }\end{array}$ \\
\hline
\end{tabular}


Keberhasilan kegiatan pengabdian ini disambut baik oleh Kepala Kelurahan Gilingan, Banjarsari, Surakarta dan para peserta. Pimpinan dan masyarakat Kelurahan Gilingan, Banjarsari, Surakarta berharap untuk dapat dilakukan kegiatan serupa dengan tema yang berbeda.

\section{KESIMPULAN}

Kegiatan pengabdian masyarakat yang telah dilakukan meningkatkan pemahaman dari perwakilan lansia, Kader PKK dan Kesehatan tentang penyakit stroke dan penanganannya secara alami serta melalui perubahan gaya hidup sehingga diharapkan dapat disosialikan kepada seluruh masyarakat di Kelurahan Gilingan, kecamatan Banjarsari, Surakarta dan dapat mengurangi angka kejadian stroke.

\section{UCAPAN TERIMAKASIH}

1. Hartono, M.Si., Apt., selaku Ketua STIKES Nasional yang telah memberikan izin untuk kegiatan pengabdian masyarakat ini.

2. Tri Harningsih, S.Si., M.Si., selaku Ketua LPPM STIKES Nasional atas kesempatan dan saran yang diberikan selama melakukan kegiatan pengabdian masyarakat ini.

3. Joko Partono, S.T., M.Si., selaku Kepala Kelurahan Gilingan atas izin lokasi, kesempatan, dan fasilitas yang telah diberikan selama pelaksanaan pengabdian masyarakat ini.

4. Kader PKK, Kader Kesehatan, dan Perwakilan Lansia Kelurahan Gilingan, Kecamatan Banjarsari, Surakarta atas partisipasi dan kerjasamanya dalam pengabdian masyarakat ini.

\section{DAFTAR PUSTAKA}

Aminoff, M. J., Greenberg, D. A., \& Simon, R. P. (2009). Clinical Neurology (7th ed.). New York: McGraw-Hill Education.

Diwanto, M. A. (2009). Tips Mencegah Stroke, Hipertensi dan Serangan Jantung. Yogyakarta: Paradigma Indonesia.

Fagan, S. C., \& Hess, D. C. (2008). Stroke. Dalam Pharmacotherapy A Pathophysiologic Approach (6th ed.). United States of America: The McGraw-Hills Companies.

Gofir, A. (2009). Manajemen Stroke. Yogyakarta: Pustaka Cendekia Press.

Goldszmidt, A. J., \& Caplan, L. R. (2011). Esensial Stroke. Jakarta: EGC.

Setyopranoto, I. (2011). Stroke: Gejala dan Penatalaksanaan. Cermin Dunia Kedokteran (Vol. 38 Issue. 4 ), (pp. 247-248).

Sweetman, S. C. (2009). Martindale: the complete drug reference (36th ed.). London: Pharmaceutical Press. 